\title{
Business Cycle and TPM of TNCs
}

\author{
Junrong Liu \\ School of Tourism and Management \& Economics, Leshan Normal University, Leshan, China \\ E-mail: liujr@lsnu.edu.cn \\ Received June 23, 2011; revised July 26, 2011; accepted August 5, 2011
}

\begin{abstract}
This article is devoted to analyses on effects of the four phases of business cycle on transfer pricing manipulation (TPM) of transnational corporations (TNCs) and TNCs' possible TMP practices through business cycle. The researcher herein holds that business cycle arouses the fluctuation of economical indicators and policy changes, which subsequently affect TNCs' production, financial situation, sales and their resource allocation globally. Acting as a reasoning business being, TNCs should take according strategies to manipulate transfer pricing to harbor the possible benefit and escape from any risk ahead, by taking advantage of their "Trans-nationality".
\end{abstract}

Keywords: Business Cycle, Transfer Pricing, Manipulation, TNCs

\section{Introduction}

Economic cycle is an objective economic phenomenon, which affects all economic activities and government economic policies. Multinationals' transfer pricing in internal trade also be subjected to economic cycles. And the impact of economic circular fluctuations on the market and government policy changes directly influence multinational transfer pricing strategies and the transferring direction, which, without the proper management, would cause great waste of resources. In view of this, this paper is sacrificed to that the exploring the impacts of evolution of economic cycle four phases on the transfer pricing manipulations (TPMs) of the multinationals' intra-firm trade.

\subsection{The Motivation of Internalization}

Transnational companies in nature are the results of internationalized internalization of firms' trade and the economic organizations that are capable of harboring the best resources in the world, to seeking for the maximum market profits at the lowest cost. Unless the consideration for long-term strategy, they always try to avoid all negatives. Actually, the instinct advantages TNCs have are not their vast resources and the advanced technology and management techniques but their Trans-Nationality as the core advantage. Multinational corporations, according to the level of technology and specialization in different countries, take the international specialized production strategies and construct the network of sentinel production of specialized factories worldwide, and spare parts' manufacturing division and logistics leading to the favorable locations, assembling bases and direct marketing sub-centers. In order to face up the fierce market competition, Transnational corporations have production activities in different countries linked together through the production system, which covers investment and trade activities, and convert a majority of their trade into intra-firm trade among the parent company and subsidiaries or among the affiliates. [1,2] The trans-nationality of TNCs makes them enjoy the broad geographical space, wide market and convenient finance, and thus renders TNCs much mobility in dealing with various risks.

\subsection{The Functions of Transfer Pricing}

Trade Internalization has made TNCs' trans-nationality effective and enables them to make up international operating costs, harboring their competitive advantage. [3] Internalization theories hold that because of external market's defects that raise market transaction costs, TNCs prefer internal transactions to external market transactions. Internal transfer pricing refers the pricing manipulation on products, services, intangible assets and funds so on, which are transacted within TNCs. Transfer Pricing Manipulation (TPM) is a practice by TNCs in making prices that would be higher or lower than the opportunity cost to avoid (not to evade illegally) national con- 
trol or take opportunity to exercise arbitrage strategies.

As the world market is not fully unified one, TNCs can be the beneficiary of international operations. The effective use of the global production and marketing network makes the feasibility of transferring resources within firms become the TNCs advantage which is exclusive to any Non-TNCs.[4] TNCs' transfer pricing operations is the right practice in taking the advantage of defects in the global market to achieve their business goal. [5]

\section{The Impact of the Economic Variables on TNCs' TPM}

The economic variables herein are the macroeconomic indicators which states business cycle, including exchange rates, tax rates, interest rates, GDP growth rates and market consumption situation and so forth. Before discussing the impacts of the economic cycle on TPM by multinational corporations, we should come to the impact of the economic variables on TNCs' TPM.

\subsection{Exchange Rates}

Exchange rate is the monetary value ratios between the two nations' currencies. The appreciation or depreciation of one nation's currency would create arbitrage opportunity between two counties in a short time, which, for TNCs with a huge amount of fund, is an excellent profit opportunity. Such arbitrage should be necessarily reflected in the internal trade pricing, and the popular practices are over-pricing or under-pricing the assets to be internationally internally transacted so as to achieve their financial returns with the changes of exchange rate.

\subsection{Tax Rates}

Changes in tax rates also exert obvious influence on transferring pricing of TNCs. Some scholars even believe that TNCs manipulate transfer pricing primarily for tax avoidance or evasion. [7] TNCs generally achieve tax avoidance in two ways through transfer pricing: First way is the over-pricing of transfer-in to drive up cost for tax reduction, and the other is to shift profits to the branches in low tax countries. [6,8,9]The two methods can be applied by the companies who are in the countries of high tax rate. When the host countries' tax rate is low, the more effective method for tax avoidance should be the choice; Of course, compared with other countries, the host country's tax rate is very low or even free (say, that in FTZ), low-priced transfer-out and high-priced transfer in seem to be the best policy.

\subsection{Interest Rates}

A question worthy of further exploration is the importance of interest rate changes to TNCs. transfer pricing issues. Any fluctuation in interest rates in host country would change the financing cost of TNCs costs in the country. In the case of low interest rates, TNCs can easily harbor financial resource at low cost, and they decline in this time directly to transferring the low-cost capital to their brunches in the nations of high interest rates. If there is limitation over the transfer (the policy constraints mainly), these funds may be transferred in disguise of production equipment or management aids to the highinterest rate countries through the intra-trade channels; Additionally, TNCs also transfer their financial assets to parent company or foreign branches, thus saving fund, lower costs and improving return on assets. Largely, these behaviors of TNCs are arbitrage practices over the gap of international interest rates. The transfer prices can be determined with TNCs' considering the exchange rate and tax rates. Given their economic variables are constant, low interest rates would lead to in-transferring at high prices and out-transferring at low prices and vice versa.

\subsection{GDP Growth Rate}

GDP growth rate is the basic indicator of economic conditions and the main measurement of business cycle. Higher growth rate of GDP indicates that the economy is in booming phase, when firms enjoy a favorable business climate for development and need more tangible assets and equipment for production and operation, and have accumulated many new technologies since the previous phases. In the case of slow GDP growth, corporate suffer sluggish sales and underproduction and enlarging inventory, TNCs then generally move their idle equipment to the booming economies where their branches or parent company are. According general economic theories and practice, in the four phases of economic cycle, governments usually adopt an "anti cycle methodology" to regulate their national economies. In the period of economic expansion, government monetary and fiscal policies are always featured with high tax rate and high interest rate; while in a recession, the governments largely adopt a low tax rates and low interest rate. The changes in GDP form the immediate impact on people's income and consumption power, thereby affecting the prices of products and marketing of TNCs.

In addition, GDP growth and exchange rate have a close relationship. Therefore, changes in GDP would immediately influence the transfer pricing manipulation (TPM) of TNCs mainly with changes in the economic 
development and the relevant adaptation of government policies concerning tax rates, interest rates, exchange rates etc. Largely speaking, when GDP grows rapidly, TNCs will exercise high priced transfer-out of physical assets for the production in other locations and lowpriced transfer-in of intangibles such as technology for product upgrading and innovation. While the GDP growth rate is high, TNCs then employ the manipulation of high-priced transfer-out and low-priced transfer-in, and the former transferred are mainly invisible assets such as technologies while the latter intra-transacted are the physical assets concerning production.

\subsection{Consumption Power}

The consumption power is another key indicator which reflects market size that possibly taken by TNCs. In general, the low consumption means the small demand on the market and vice versa. In fact, market conditions faced by TNCs hardly affects directly their transfer prices, but given combined with other factors, it would make big difference.

Based on the above analyses, the economic cycle will cause changes in exchange rates, tax rates, interest rates, GDP growth rates, market conditions and even political stability and consumption changes, which drives TNCs to take different transfer pricing strategies. For convenience, we exhibit the relationship between TNCs' TPM and Changes in economic variables in the table below.

\section{The Business cycle and the TNCs' TPM}

\subsection{The Impact of the Evolution of Business Cycle Phases on TNCs}

Briefly speaking, the impacts of economic cycle on TNCs can be generalized as follows: first, the change in consumption leads to fluctuation in the sales' of TNCs. Usually, the economic downturn is accompanied with the decline in national income and weak investment, which lead to deep reduction of consumption, and thereby make TNCs suffer the enlarging product backlog or underproduction, resulting in high business opportunity cost and low capital efficiency. Second, the governmental adjustment over the policies has great implications to TNCs' operation. Faced with cyclical economic fluctuation, the local governments will make macro-control policies to deal with the adverse changes in the economy, which would conflict with TNCs' established strategic and plans and influence firms' operations negatively. Third, the economic circular fluctuation sometimes jeopardizes TNCs' assets. Large fluctuations in the economy may be accompanied by political events and even wars, and di-
Table 1. The Relationship between TNCs' TPM and Changes in Economic Variables.

\begin{tabular}{cccc}
\hline Variables & Change & $\begin{array}{c}\text { Transfer price } \\
\text { (outward) }\end{array}$ & $\begin{array}{c}\text { Transfer price } \\
\text { (inward) }\end{array}$ \\
\hline \multirow{2}{*}{ Ex-rate } & up & HP & LP \\
& down & LP & HP \\
Tax rate & low & HP & LP \\
& high & LP & HP \\
Int-rate & low & HP & LP \\
& high & LP & HP \\
Growth & low & HP & LP \\
-rate & high & (intangibles) & (physicals) \\
& (physicals) & HP \\
Consum. & down & LP & (intangible ) \\
power & up & HP \\
& (intables) & (physicals) \\
(physicals) & LP \\
(intangibles)
\end{tabular}

rectly endanger the security of the assets of transnational companies, and the possible dangers would be destruction, expropriation and confiscation and prohibition of profit repatriation and so on.

For transnational corporations, the economic risks of cyclical fluctuations are frequent, and one of the effective means TNCs take to avoid these risks is to take advantage of their existing global operation network to reallocate their resources through internal transfer of both tangible and intangible assets. This transfer must involve pricing the goods to be transferred. For the transfer of assets within the enterprise makes no difference on ownership, transfer pricing thus seems unimportant. However, due to the trans-nationality of the intrafirm transfer of TNCs' assets, which involves differences in international tax, currency exchange rates [10], national economic sovereignty, and TNCs' benefit internaldistribution, TNCs' transfer pricing becomes necessary. Actually, internal transfer pricing allows the TNCs' cross-boarder transfer of assets the legitimacy of exporting, which enables TNCs to evade tax legally and avoid some possible high political risks from their considerable arbitrage profits.

The economic cyclical fluctuations have their own different characteristics in each phase of business cycle, thus TNCs' transfer pricing face variable economic policies, which drives firms to adjust their business objectives and transfer pricing manipulation. In this paper, we employ the methodology of John. R. Mayer and Daniel. H. Weinberg, who held that a complete economic cycle consists of the four phases: recession, recovery, demandpull inflation and prosperity. And, we maintain that the evolution of business cycle has significant implication for TNCs, and would bring about changes which powerfully influence TNCs' performance, such as national tax 
policy change, the changes in exchange rates and interest rates, the changes in, and as an unusual situation, the risks over ownership of TNCs' asset from political risks.

Before The analysis over the impacts of the four phases on TNCs' transfer pricing, we first make the following assumptions: First, the governments act on the theories of business cycles; Second, the enterprises respond to the outside environmental change and the adjustment in economic policies in accordance with the "rational economic man" approach; Third, all countries (say country A and country B) be at different phases of business cycles; Fourth, national economic activity are independent from the political ideology; Fifth, other factors within enterprises are fixed. The purpose of these assumptions is to simplify our analysis, and in fact, these assumptions are consistent with economic theories and the traditional practice of general economic activity.

1) Economic recession. In recession phase of business cycle, the particular country (say country A) adopts loose monetary and fiscal policies of economic expansion, say lower interest rates, low tax rate and high governmental transfer and so on. In the economic downturn phase, the Government welcomes the entry of foreign capital, while the outflow of assets and funds are under strict control; At this time, tax rate decreased significantly, while the country's currency is expected to appreciate; And the difficulties faced with by TNCs are baggy consumption, sluggish sales, rising inventories and underemployment.

2) Economic recovery. In this period, the country (country A) will continue to maintain accommodative monetary and fiscal policy, and hold the welcoming attitude to foreign investment, but policy efforts are to be weakened, and the market conditions faced by transnational corporations continue to improve, sales increase, and excess inventory decreases.

3) Demand-driven inflation. Because people's demand and investment are increasing, the economy grows rapidly, but the signs of inflation become clear for faint, while the economy is still being steadily improved. Meanwhile, the government policies turn neutral and hence the preferential policies offered by government to TNCs have gone. However, at this time, TNCs enjoy better business climate with increasing product sales, boosting corporate income and a gradual expansion of production and larger market share. The only drawback is that the cost of TNCs expresses a significant upward trend, which further encourages the inflation in the country, and change in exchange rate will makes TNCs suffer losses in profit repatriation and from export.

4) Economic booming. With the further development of the economy, the country (country A) entered the boom phase of business cycle, with rapid production promotion, investment scale-up, credit expansion, the price level rising and increasing employment. Meanwhile, consumer demand is climbing up and the market is in its expansion. At this stage, the macroeconomic contains two forces, that is, the power driving economy to grow and the strength forcing the economy down-turning. In the boom phase, the country (country A) mainly takes tight monetary policies and fiscal policies to deal with the economic overheating, and thereby the bank interest rates rise, and corporate tax increase. The government would manage the expectation of investment revenue to control the total investment, thus preventing the economy from reducing to be of recession from excessive expansion. In this phase, the government in short run restricts the entry of foreign capital, while depreciation of the currency lies under strong expectation, which brings some detriment on TNCs in profit repatriation and exporting. And in spite of increasing corporate sales, due to the rise of costs, TNCs' actual profit would drop from that of the previous phase, making TNCs lack for motivation for business expansion.

\subsection{The TPM Employed in Each Phase}

With the environment faced by the four stages pictured above, TNCs will employ transfer pricing strategy accordingly in order to achieve reasonable tax avoidance, and thus optimize the global resource allocation, corner greater arbitrage opportunities and ensure the efficiency of asset proliferation.

1) The TPM in recession

At this stage, due to underemployment and glissading sales, TNCs will ship resources in a branch in a particular country (country A) to its sister branch in another country (country B)to ensure the effective use of total corporate resources. Country A in recession should take low-tax policies to stimulate economic development, whereby TNCs would transfer out at high-price to enjoy the advantages of low taxation; Additionally, because the currency of country A are to appreciate, TNCs can corner arbitrage opportunities for exchange rate fluctuation. For TNCs in any country in recession, they are witnessing the market shuffle and product upgrading, so they would transfer out tangible assets concerning production, operation and management through intra-trade channel, and move into technologies at low prices to equip the new production for the future market. Besides the transfer of capital, TNCs can also take advantage of the loose monetary polices to financing in country A and then transfer the fund to country B, reducing corporate costs and enhancing asset utilization, harbor tax relief and international arbitrage opportunities.

2) The TPM in recovery

In the economic recovery period, as TNCs face the similar fiscal and monetary policy with that in economic recession, their transfer pricing strategy is also roughly 
the same. With minor policy changes, there are some adjustments within TPM of TNCs. At this time, with the gradual economic recovery of country A and vigorous market, TNCs gradually cater for the economic improvement and start transferring in intangible assets (such as Proprietary technology, trademarks, patents) at low price to meet the increasing production in country $\mathrm{A}$, when transfer-out at high price is still dominant.

3) The TMP in demand-driven inflation

At this stage, the government policies of country A become neutral and the nation is suffering the pressure of the devaluation of its currency. The low tax policy advantages enjoyed by TNCs have disappeared, while the demand-driven inflation in the country A makes the value of international assets of TNCs shrinking. However, the current active market and greater profit margins in this country provide TNCs a better business climate. Considering the advantages and disadvantages synthetically, TNCs will transfer out mainly intangible assets at low price, while transfer in the tangible assets concerning production, operation and management from country B to meet the production requirement and capital needs in country A, thus they increases the carrying cost, and thereby circumvent the tax in country A and the loss of assets from currency depreciation, and access to arbitrage opportunities in country B. The period is the prime season for TNCs' business operation, and in this phase, enterprises should consider not only the in-transferring but the out-transferring for the local high tax rate and the security of their assets.

4) The TMP in economic boom

In economic boom phase, the government usually exercise tight fiscal and monetary policies, that is, high tax rate and high interest rates; And the country (country A) suffers high inflation and currency devaluation; Besides, market gets saturated and competition fierce; Fourth, TNCs have large corporate sales, but profit margins are narrow; Additionally, in this time, the factors economic growth and recession coexist. To response to this adverse environment, TNCs mainly forth-put the low price policy in intra-trade transfer pricing, which aims to 1) avoidance of tax, 2) preventing the devaluation of assets from currency depreciation, 3) avoiding inefficient use of corporate assets. Therefore, the usual TPMs are transferring out the resources at low price to the efficient production location (say country B) for high capital revenue and transferring in technologies and patents at high price to upgrade products for future competition.

\subsection{Generalization}

Based on the argument above, we generalized TNCs' TPM in Table 2 and Figure 1 as follows:
Table 2. Business cycle, Economic variables and TPM.

\begin{tabular}{ccccccc}
\hline $\begin{array}{c}\text { Phases } \\
\text { of Business } \\
\text { cycle }\end{array}$ & $\begin{array}{c}\text { Tax rate } \\
\text { and Ex-rate }\end{array}$ & $\begin{array}{c}\text { INT- } \\
\text { rate }\end{array}$ & $\begin{array}{c}\text { GDP } \\
\text { growth } \\
\text { rate }\end{array}$ & $\begin{array}{c}\text { Consum- } \\
\text { ption }\end{array}$ & $\begin{array}{c}\text { TPM } \\
\text { Inward } \\
\text { (price) }\end{array}$ & $\begin{array}{c}\text { TPM } \\
\text { Outward } \\
\text { (price) }\end{array}$ \\
\hline Recession & $\mathrm{L}$ & $\mathrm{L}$ & $\mathrm{L}$ & $\mathrm{L}$ & $\mathrm{L}$ & $\mathrm{H}$ \\
Recovery & $\mathrm{L}$ & $\mathrm{L}$ & $\mathrm{L}$ & $\mathrm{L}$ & $\mathrm{L}$ & $\mathrm{H}$ \\
Inflation & $\mathrm{H}$ & $\mathrm{H}$ & $\mathrm{H}$ & $\mathrm{H}$ & $\mathrm{H}$ & $\mathrm{L}$ \\
Boom & $\mathrm{H}$ & $\mathrm{H}$ & $\mathrm{H}$ & $\mathrm{H}$ & $\mathrm{H}$ & $\mathrm{L}$ \\
\hline
\end{tabular}

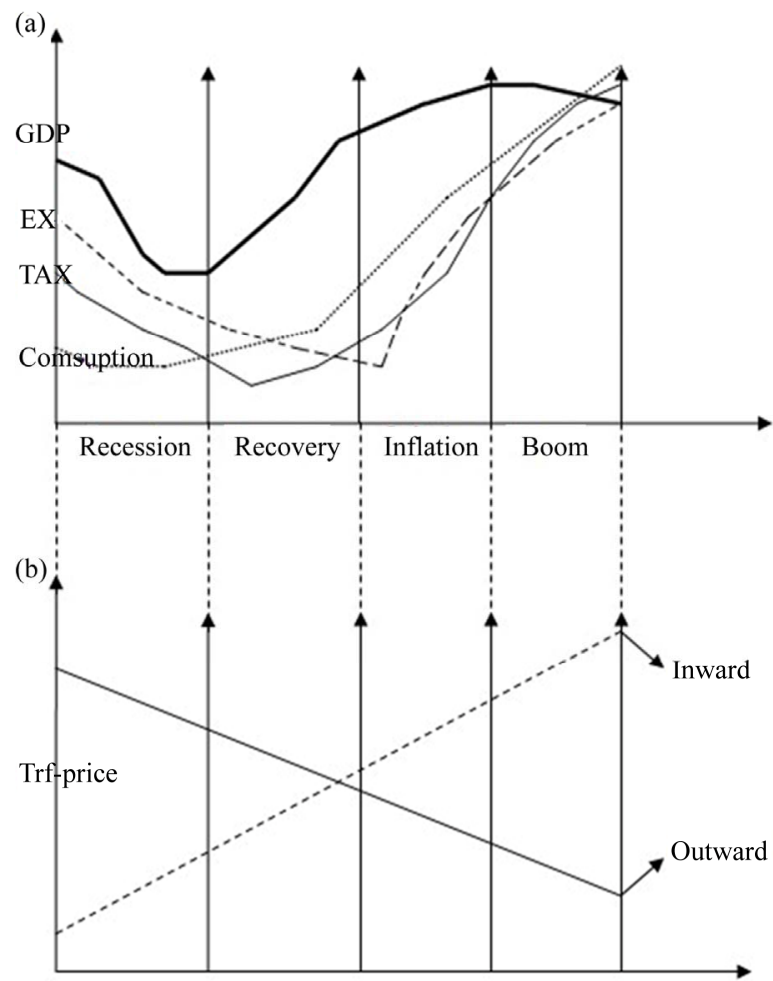

Figure 1. Schematic diagram of business cycle \& TPM.

\section{Concluding Remarks}

Business cycle affects all factors of economy, and the factors directly affect the pricing products and services transacted within TNCs. This paper merely theoretically analyzes the impact of business cycle on TNCs transfer pricing. Anyhow, this study has its due some implication for government administration and enterprise governance. The findings of the paper show that within the four stages of business cycle, TNCs take a different transfer pricing strategies, and these strategies come out of TNCs property of "rational economic being", which would offset the local government "counter-cycle" policies, aggravating economic overheating, exacerbating economic recession and inflation. In addition, this study helps our understanding TMP of TNCs in each phase of business cycle, which provides the government with a perspective to view of TNCs' TPM and better their policy making. 


\section{References}

[1] Hirshleifer and Jack, "On the Economics of Transfer Pricing,” Journal of Business, Vol. 29, 1956, pp. 172-83. doi:org/10.1086/294110

[2] Zeile and J. William, "U.S. Intrafirm Trade in Goods," Survey of Current Business, Vol. 2, 1997, pp. 23-38.

[3] K. S. Cravens, "Examining the Role of Transfer Pricing as a Strategy for Multinational Firms," International Business Review, Vol. 2, No. 6, 1997, pp. 127-145. doi:org/10.1016/S0969-5931(96)00042-X

[4] B. Kogut, and K. Nalin, “Operating Flexibility, Global Manufacturing and the Option Value of a Multi- national Network,” Management Science, Vol. 1, No. 40, 1994, pp. 123-39. doi:org/10.1287/mnsc.40.1.123

[5] E. Lorraine, "The Internalization Benefits of Transfer Price Manipulation,” December 2003, Bush School Working Paper 315\#, p. 4.
[6] Hines and James, "Lessons from Behavioral Responses to International Taxation,” National Tax Journal, Vol. 2, No. 52, 1999, pp. 305-310.

[7] Horst and Thomas, "Theory of the Multinational Firm: Optimal Behavior under Differing Tariff and Tax Rates," Journal of Political Economy, Vol. 10, No. 79, 1971, pp. 1059-1072. doi:org/10.1086/259814

[8] H. M. Rober and S. Bin, "U.S. Income Tax Transfer Pricing Rule and Resource Allocation: The Case of Decentralized Multinational Firms," The Accounting Review, Vol. 66, No. 1, 1991, pp. 141-156.

[9] Roger and Y. W. Tang, "Environmental Variables of Multi- national Transfer Pricing: AU.K. Perspective," Journal of Business and Accounting, Vol. 2, No. 9, 1982, pp. 179-189.

[10] Abdallah and M. Wagdy, "How to Motive and Evaluate Managers with International Transfer pricing System," Management International Review, Vol. 29, No. 1, 1989, pp. 35- 40 . 